\title{
PENERAPAN PRINSIP NON-DISKRIMINATIF DAN NATIONAL TREATMENT OLEH INDONESIA DALAM RANGKA MEA BERDASARKAN UNDANG-UNDANG NOMOR 25 TAHUN 2007 TENTANG PENANAMAN MODAL
}

\author{
Nurhani Fithriah \\ Fakultas Hukum Universitas Padjadjaran \\ Email : nurhanifithriah99@gmail.com
}

\begin{abstract}
Indonesia, which was incorporated in the United Nations, also took the first step in the policy ratified by the agreement to form the WTO through Law No.7 of 1994, namely the attachment to implementing all the results of the Uruguay negotiation agreement. Foreign investment regulations are actually not explicitly contained in the WTO agreement, but explicitly appear in the formulation of the principles of free trade specifically related to the principle of non-discrimination which includes Most Favored Nation (MFN) and National Treatment Principle (NT). Foreign investment is a solution for developing countries, such as Indonesia to optimize the management of natural resources and economic potential (economic resources) so that they are of higher value. The establishment of Law Number 25 of 2007 concerning Investment is intended to attract foreign investors and domestic investors. The problems that will be discussed in this paper are related to the obligation to apply the principle of non-discrimination and National Treatment or the same treatment for foreign investors in Indonesia and the application of the principle of Non-Discriminative and National Treatment in the case of Indonesian National Car Procurement. The conclusion obtained was that the Indonesian Government had applied the principle of NonDiscriminatory and National Treatment by applying the principle in Law Number 25 of 2007 concerning Investment. Indonesia also applied the Non-Discriminatory Principles and National Treatment in the Case of Procurement of Indonesian National Cars by undergoing a ruling requiring the Indonesian Government to revoke all Presidential Decrees along with other Regulations related to local content requirements.
\end{abstract}

\section{Keywords : Implementation; Non Discriminative; National Treatment; Foreign Investment}

\section{ABSTRAK}

Indonesia yang tergabung dalam PBB turut mengambil langkah awal dalam kebijakan yang diratifikasi dengan persetujuan pembentukan WTO melalui Undang-undang No.7 tahun 1994, yakni keterikatan untuk melaksanakan seluruh hasil kesepakatan perundingan Uruguay. Peraturan penanaman modal asing sesungguhnya tidak secara tegas termuat dalam perjanjian WTO, namun secara eksplisit muncul dalam rumusan prinsip-prinsip perdagangan bebas khususnya terkait prinsip non diskriminasi yang meliputi Most Favoured Nation (MFN) dan National Treatment Principle (NT). penanaman modal asing merupakan solusi bagi negara-negara berkembang, seperti Indonesia untuk mengoptimalkan pengelolaan sumber daya alam dan potensi ekonomi (economic resource) agar bernilai lebih tinggi. Dibentuknya Undang-Undang Nomor 25 Tahun 2007 tentang Penanaman Modal dimaksudkan untuk menarik investor asing dan investor dalam negeri. Permasalahan yang akan dibahas dalam 
tulisan ini yaitu terkait kewajiban diterapkannya Prinsip non-diskriminatif dan National Treatment atau perlakuan yang sama bagi penanam modal asing di Indonesia dan penerapan prinsip Non-Diskriminatif dan National Treatment dalam kasus Pengadaan Mobil Nasional Indonesia. Kesimpulan yang didapat yakni Pemerintah Indonesia sudah menerapkan prinsip Non-Diskriminatif dan National Treatment dengan menerapkan prinsip tersebut di dalam Undang-undang Nomor 25 Tahun 2007 tentang Penanaman Modal. Indonesia juga menerapkan Prinsip Non-Diskriminatif dan National Treatment dalam Kasus Pengadaan Mobil Nasional Indonesia dengan menjalani putusan yang mewajibkan Pemerintah Indonesia mencabut semua Keputusan Presiden beserta Peraturan lainnya yang terkait dengan persyaratan kandungan lokal.

\section{Kata Kunci : Penerapan; Non-diskriminatif; Perlakuan yang sama; Penanaman Modal Asing}

\section{Pendahuluan}

Pada era internasionalisasi, Indonesia yang tergabung dalam PBB turut mengambil langkah awal dalam kebijakan yang diratifikasi dengan persetujuan pembentukan WTO melalui Undang-undang No.7 tahun 1994 yang berarti bahwa Indonesia memiliki keterikatan untuk melaksanakan seluruh hasil kesepakatan perundingan Uruguay yakni Kesepakatan mengenai kebijakan pembatasan investasi yang terkait dengan perdagangan atau Trade Related Investment Measures (TRIMs), kesepakatan mengenai aspek-aspek Hak Kekayaan Intelektual yang terkait dengan Perdagangan atau Trade Related Aspects of Intelectual Property Rights (TRIPs) dan Kesepakatan Umum mengenai Perdagangan Jasa Atau General Agreement on Trade in Service (GATS).

Peraturan penanaman modal asing sesungguhnya tidak secara tegas termuat dalam perjanjian WTO baik dalam Agreement on TRIMs maupun GATS namun secara eksplisit muncul dalam rumusan prinsip-prinsip perdagangan bebas yang telah dinegosiasikan dalam putaran Uruguay sejak tahun 1947. khususnya terkait prinsip non diskriminasi yang meliputi Most Favoured Nation (MFN) dan National Treatment Principle (NT). MFN menghendaki pemberian perlakuan sama kepada Negara yang satu dengan Negara yang lain oleh Negara penerima penanaman modal sedangkan prinsip NT mensyaratkan adanya perlakuan sama antara produk Negara tuan rumah dengan produk serupa dari luar negeri. ${ }^{1}$ Prinsip yang terakhir terdapat dua kepentingan yang berhadap-hadapan secara langsung yaitu kepentingan nasional untuk melindungi produk dalam negeri dari persaingan dengan produk luar negeri dan kepentingan internasional yang menghendaki persaingan bebas dengan kesempatan yang sama.

Prinsip National Treatment melarang peraturan-peraturan diskriminatif sebagai alat

${ }^{1}$ Muhammad Sood. Hukum Perdagangan Internasional, Jakarta: PT Raja. Grafindo Persada, 2012. Hlm. 25 
untuk memberikan proteksi terhadap produk dalam negeri. Termasuk didalamnya tindakan-tindakan perpajakan dan pungutanpungutan lainnya. Prinsip ini juga berlaku pula terhadap Perundang-undangan, pengaturan dan persyaratan-persyaratan hukum yang dapat mempengaruhi penjualan, pembelian, pengangkutan distribusi atau penggunaan produk-produk di pasar dalam negeri dan pemberian perlindungan terhadap proteksionisme sebagai upaya-upaya atau kebijakan administratif atau legislatif. ${ }^{2}$

Bagi Negara-negara berkembang dan terbelakang kebijakan pembatasan terhadap penanaman modal asing masih diperlukan untuk melindungi kepentingan nasional mereka dari persaingan yang tidak seimbang antara industri domestik dengan modal dan sumberdaya terbatas melawan perusahaanperusahaan multinasional yang jelas-jelas jauh lebih hebat dalam bidang permodalan maupun tehnologi. Persaingan bebas murni hanya dapat diterapkan apabila para pemainnya berada dalam kondisi yang setara.

Sebagai Negara yang berdaulat secara hukum maupun politik, Indonesia sejak awal pendirianya telah menentukan bentuk perekonomiannya. Hal tersebut dibentuk bersama berdasar atas asas kekeluargaan, cabang-cabang produksi yang penting dan

\footnotetext{
${ }^{2}$ Mahmul Siregar, Perdagangan Internasional dan Penanaman Modal, Universitas Sumatera Utara. Sekolah Pasca Sarjana. 2005. Hlm. 68
}

menguasai hajat hidup orang banyak dikuasai oleh Negara. Bumi, air dan kekayaan alam yang terkandung di dalamnya dikuasai oleh Negara dan dipergunakan untuk sebesarbesar kemakmuran rakyat sebagaimana tertuang dalam Pasal 33 Undang-undang Dasar 1945. Perekonomian Nasional diselenggarakan berdasar atas demokrasi dengan prinsip kebersamaan, efisiensi berkeadilan, berkelanjutan, berwawasan lingkungan, kemadirian serta dengan menjaga keseimbangan kemajuan dan kesatuan ekonomi nasional.

Berdasarkan pertimbangan tersebut, penanaman modal asing merupakan solusi bagi negara-negara berkembang, seperti Indonesia untuk mengoptimalkan pengelolaan sumber daya alam dan potensi ekonomi (economic resource) agar bernilai lebih tinggi. Hai ini pada akhirnya dapat meningkatkan kesejahteraan rakyat. Oleh sebab itu, persaingan antar negara untuk menarik masuk investor ke negaranya sudah sedemikian ketat. Bentuk kebijakankebijakan yang ramah terhadap investor asing dan investor dalam negeri untuk menanamkan modalnya di Indonesia merupakan hal yang penting. Dibentuknya Undang-Undang Nomor 25 Tahun 2007 tentang Penanaman Modal atau yang kemudian disebut UUPM dimaksudkan untuk menarik investor asing dan investor dalam negeri. Kebijakan tersebut dibuat dengan tidak ada pembedaan atau 
diskriminasi perlakuan hukum diantara keduanya. Berdasarkan latar belakang yang sudah dijabarkan sebelumnya, maka identifikasi yang diangkat, yaitu: Bagaimanakah Pemerintah Indonesia dalam menyikapi kewajiban diterapkannya Prinsip non-diskriminatif dan National Treatment atau perlakuan yang sama bagi penanam modal asing di Indonesia? Bagaimanakah penerapan prinsip NonDiskriminatif dan National Treatment dalam kasus Pengadaan Mobil Nasional Indonesia?

\section{Pembahasan}

Pemerintah Indonesia dalam Menyikapi Kewajiban Diterapkannya Prinsip NonDiskriminatif dan National Treatment Bagi Penanam Modal Asing Di Indonesia

\section{Prinsip Non-Diskriminatif dan National}

\section{Treatment berdasarkan Undang-}

undang Nomor 25 Tahun 2007 tentang

Penanaman Modal

Perlakuan terahadap Penanaman Modal disebutkan dalam Pasal 6 ayat (1) dan (2) UUPM yaitu: (1) Pemerintah memberikan perlakuan yang sama kepada semua Penanam Modal yang berasal dari Negara manapun yang melakukan kegiatan Penanaman Modal di Indonesia sesuai dengan ketentuan peraturan perundang-undangan. (2) Perlakuan sebagaimana dimaksud pada ayat (1) tidak berlaku bagi Penanam Modal dari suatu Negara yang memperoleh hak istimewa berdasarkan perjanjian dengan Indonesia.
Perlakuan terahadap Penanaman Modal disebutkan dalam Pasal 7 UUPM yaitu: Pemerintah tidak akan melakukan tindakan nasionalisasi atau pengambilalihan hak kepemilikan Penanaman Modal, kecuali dengan Undang-Undang. Dalam hal Pemerintah melakukan tindakan Nasionalisasi. Perlakuan terahadap Penanaman Modal disebutkan dalam Pasal 8 ayat (5) yaitu: Ketentuan sebagaimana dimaksud pada ayat (1) tidak mengurangi: a) Kewenangan Pemerintah untuk meberlakukan ketentuan peraturan Perundang-undangan yang mewajibkan pelaporan pelaksanaan transfer dana. b) Hak Pemerintah untuk mendapatkan pajak dan/atau royaltidan/atau pendapatan pemerintah lainnya dari Penanaman Modal sesuai dengan ketentuan peraturan perundang-undangan. c) Pelaksanaan hukum yang melindungi hak kreditor dan pelaksanaan hukum untuk menghindari kerugian Negara.

\section{Adapun Pasal 9 UUPM yang} mengatur tentang Penanaman Modal dalam prinsip Non Diskriminasi yaitu: 1) Dalam hal adanya tanggung jawab hukum yang belum diselesaikan oleh penanam modal adalah: a) penyidik atau Menteri Keuangan dapat meminta bank atau lembaga lain untuk menunda hak melakukan transfer dan/atau repatriasi; dan b) pengadilan berwenang menetapkan 
penundaan hak untuk melakukan transfer dan atau repatriasi berdasarkan gugatan.

2) Bank atau lembaga lain melaksanakan penetapan penundaan berdasarkan penetapan pengadilan sebagaimana dimaksud pada ayat (1) huruf b hingga selesainya seluruh tanggung jawab penanam modal.

Namun dalam hal ini tetap ada pemberlakuan pembedaan terhadap Penanaman Modal Asing seperti, bentuk badan usaha dan bidang usaha yang terbuka, yang tertutup. Sedangkan untuk penanam modal asing diharuskan berbentuk Perseroan Terbatas, kecuali undang-undang menentukan lain.

Indonesia telah merealisasikan prinsip non-diskriminasi kedalam UUPM khususnya dalam Pasal 18 dengan memberikan banyak fasilitas bagi keberadaan penanam modal asing. Tetapi meskipun pemerintah memberikan fasilitas dan peluang yang sama kepada penanam modal asing sama dengan penanaman modal domestik tetapi tetap pemerintah melindungi kepentingan pengusaha domestik seperti yang tertera dalam Pasal 13 UUPM dengan mencanangkan bidang-bidang usaha khusus bagi usaha kecil menegah dan dengan menerapkan pola kemitraan antara usaha kecil menegah dan usaha besar.

\section{Persyaratan-persyaratan Penanaman} Modal Asing yang Bertentangan dengan Prinsip National Treatment

Agreement on TRIMs pada Article 2 pada prinsip melarang semua persyaratan penanaman modal yang tidak konsisten dengan article III.4 GATT 1994 tentang National Treatment yang berbunyi sebagai berikut:

"The product of any contracting party imported into the territory of any other contracting party shall be accorded treatment no less favourable that accorded to like products of national origin in respect of all laws, regulation and requirement affecting their internal sale, purchase, transportation distribution of use"

Alasan tidak adanya suatu kesepakatan tentang bentuk pasti dari persyaratan penanaman modal yang tidak konsisten dengan Article III.4 sebagaimana tertulis diatas maka Dirjen GATT memberikan illustrative list yang berisi gambaran mengenai tindakan persyaratan penanaman modal yang dilarang tersebut yaitu:

a. persyaratan untuk membeli atau kewajiban untuk menggunakan produk-produk lokal oleh perusahaan (local content requirement) atau

b. pembelian atau penggunaan produk impor yang dikaitkan dengan jumlah 
atau nilai produk lokal yang diekspor (trade balancing policy). ${ }^{3}$

Penanam Modal Asing dalam menanamkan modalnya tidak boleh melakukan hal-hal yang bertentangan dengan syarat-syarat penanaman modal asing, yaitu: ${ }^{4}$

a. Local content Requirement. Larangan untuk memberlakukan local content requirement atau persyaratan kandungan lokal dalam kegiatan penanaman modal tercantum dalam Paragraph 1.alllustrative list Agreement on TRIMs.

b. Trade Balancing Policy. Ketentuan mengenai Trade Balancing Policy diatur dalam Paragraph 1.(b)Agreement on TRIMs. Yang dimaksud dengan Trade Balancing Policy adalah persyaratan pembatasan pembelian atau penggunaan produk impor sampai jumlah tertentu yang dikaitkan dengan volume atau nilai produk lokal yang diekspor oleh perusahaan penanaman modal asing.

\section{Pencabutan Pasal 22 Undang-undang}

Nomor 25 Tahun 2007 tentang

Penanaman Modal

\footnotetext{
3 Huala Adolf, Hukum Perdagangan Internasional, Raja Grafindo Persada, Jakarta. 2004. Hlm 109.

${ }^{4}$ Dikutip dari jurnal: Dwi Martini, Judul: Prinsip National Treatment Dalam Penanaman Modal Asing Di Indonesia (Antara Liberalisasi Dan Perlindungan Kepentingan Nasional). Fakultas Hukum Universitas Mataram. 2012.
}

Pasal 22 pada UUPM dicabut oleh Mahkamah Konstitusi mengenai hak atas tanah dinyatakan kembali kepada pengaturan sebelumna yaitu yang terdapat pada Undang-undang Pokok Agraria Nomor 5 Tahun 1960. Kewenangan negara untuk menghentikan atau tidak memperpanjang Hak Guna Usaha (HGU), Hak Guna Bangunan (HGB), dan Hak Pakai tersebut tidak lagi dapat dilakukan atas dasar kehendak bebas negara. Padahal, perusahaan penanaman modal dapat mempersoalkan secara hukum keabsahan tindakan penghentian atau pembatalan hak atas tanah itu. Bagi MK, pemberian perpanjangan hak-hak atas tanah sekaligus di muka tersebut telah mengurangi dan bahkan melemahkan kedaulatan rakyat di bidang ekonomi. Pasal 22 UU No. 25 Tahun 2007 tentang Penanaman Modal pasca Putusan MK menjadi berbunyi:

1) Kemudahan pelayanan dan/atau perizinan hak atas tanah sebagaimana dimaksud dalam Pasal 21 huruf a dapat diberikan dan diperpanjang dan dapat diperbarui kembali atas permohonan penanam modal.

2) Hak atas tanah sebagaimana dimaksud pada Ayat (1) dapat diberikan dan diperpanjang untuk kegiatan penanaman modal, dengan persyaratan antara lain:

a. penanaman modal yang dilakukan dalam jangka panjang dan terkait dengan perubahan 
perekonomian Indonesia yang lebih berdaya saing;

b. penanaman modal dengan tingkat risiko penanaman modal yang memerlukan pengembalian modal dalam jangka panjang sesuai dengan jenis kegiatan penanaman modal yang dilakukan;

c. penanaman modal yang tidak memerlukan area yang luas;

d. penanaman modal dengan menggunakan hak atas tanah negara; dan

e. penanaman modal yang tidak mengganggu rasa keadilan masyarakat dan tidak merugikan kepentingan umum.

3) Hak atas tanah dapat diperbarui setelah dilakukan evaluasi bahwa tanahnya masih digunakan dan diusahakan dengan baik sesuai dengan keadaan, sifat, dan tujuan pemberian hak.

4) Pemberian dan perpanjangan hak atas tanah yang diberikan dan yang dapat diperbarui sebagaimana dimaksud pada Ayat (1) dan Ayat (2) dapat dihentikan atau dibatalkan oleh Pemerintah jika perusahaan penanaman modal menelantarkan tanah, merugikan kepentingan umum, menggunakan atau memanfaatkan tanah tidak sesuai dengan maksud dan tujuan pemberian hak atas tanahnya, serta melanggar ketentuan peraturan perundangundangan di bidang pertanahan.

Pemerintah Indonesia dalam Menyikapi Kewajiban Diterapkannya Prinsip NonDiskriminatif dan National Treatment atau
Perlakuan yang Sama bagi Penanam Modal Asing di Indonesia

Prinsip Non-Diskriminatif dan National Treatment yang diterapkan di Indonesia menjadi tidak memberikan kesempatan bagi Indonesia untuk mempromosikan industri dalam negeri. Kebijakan local content requirement dan trade balancing policy sebagai sebuah kerugian karena kesepakatan ini telah membuka paksa pasar Indonesia bagi masuknya pesaing-pesaing dari Negara yang lebih kuat. ${ }^{5}$

Melalui ketentuan ini batas-batas suatu negara tidak lagi menjadi halangan bagi lalu lintas perdagangan karena barang dan jasa akan bebas diperjual belikan di mana saja, keseluruhan negara anggota telah bersatu menjadi satu pasar bebas dan terbuka. Melalui hal ini, Indonesia menjadi berperan serta secara aktif mewujudkan iklim kondusif bagi persaingan bebas dalam perekonomian global dan mengambil manfaat dari kebijakan-kebijakan non diskriminasi tersebut bagi kepentingan nasional.

Prinsip National Treatment berpotensi untuk mengurangi konflik antar pelaku Penanam Modal Asing (PMA) yaitu Pemerintah Negara tuan tumah, Pemerintah Negara asal dan Penanam modal karena prinsip ini akan memberikan jaminan

\footnotetext{
${ }^{5}$ Martin Manurung. Diakses: http//www.indoprogress.com Diakses pada Hari Senin, 4 April 2016, Pukul 21.00 WIB.
} 
keamanan terutama bagi penanam modal. undang penanaman modal menyatakan Selanjutnya, bagi Negara penerima modal "semua bidang usaha atau jenis usaha prinsip ini memungkinkan mereka terbuka bagi kegiatan penanaman modal, memberlakukan aturan yang sama mengikatnya terhadap Investor asing dan domestik. Sehingga apabila Investor asing melakukan pelanggaran hukum yang berlaku di Indonesia maka mereka mereka akan dijerat dengan hukum yang berlaku tanpa adanya keistimewaan tertentu.

Disahkannya

UUPM yang menggantikan Undang-Undang Nomor 1 tahun 1967 tentang Penanaman Modal Asing, yang di dalamnya mengatur Prinsip national treatment menjadi salah satu semangat bagi perubahan Undang-undang tersebut diatas sebagaimana tertuang dalam Pasal 4 ayat (1) Undang-undang Penanaman Modal yang meyatakan bahwa "Pemerintah menetapkan kebijakan dasar penanaman modal untuk (a). mendorong terciptanya iklim usaha nasional yang kondusif bagi penanaman modal untuk penguatan daya saing perekonomian nasional; dan (b). mempercepat peningkatan penanaman modal. Kemudian pada ayat (2) disebutkan "dalam menetapkan kebijakan dasar sebagaimana dimaksud pada Ayat (1), pemerintah memberi perlakuan sama bagi penanam modal dalam negeri dan penanam modal asing dengan tetap memperhatikan kepentingan nasional".

Pada UUPM bidang-bidang usaha yang terbuka dan tertutup lebih akomodatif terhadap PMA, Pasal 12 ayat (1) Undang- kecuali bidang usaha atau jenis usaha yang dinyatakan tertutup dan terbuka dengan persyaratan". Pasal ini mengisyaratkan adanya persamaan perlakuan dalam pemberlakuan bidang-bidang usaha yang terbuka bagi PMA dan PMDN bahkan penyebutannya telah disamakan dengan istilah "penanaman modal.

Adanya UUPM diharapkan pertumbuhan ekonomi yang didorong investasi di sektor riil dapat memberi kontribusi signifikan bagi pembangunan namun tidak cukup sampai pengesahan Undang-undang penanaman modal saja karena pelaksanaannya akan terkait dengan Penyelesaian RUU Perpajakan serta aturanaturan pelaksanaan lainnya.

UUPM sebagai suatu regulasi di bidang Penanaman Modal Asing bukan semata-mata mengenai perdagangan Internasional saja. UUPM juga merupakan hal yang berhubungan dengan pengaturan ekonomi secara makro mengingat PMA berkaitan langsung dengan sumberdaya-sumberdaya nasional yang ada. Tidak dapat dipungkiri banyak pihak menganggap bahwa prinsip National Treatment justru telah semakin melapangkan jalan Multi National Corporation (MNC) untuk berkembang di segala penjuru dunia karena sebuah Negara harus memberikan perlakuan sama terhadap 
pengusaha dalam negeri dengan pengusaha dari Negara anggota lainnya.

Semakin mudahnya akses pasar ini persaingan akan semakin tajam. Ditambah dengan posisi tawar yang sama dikhawatirkan dalam prakteknya akan berlaku hukum alam siapa yang lebih kuat dia yang menang. Indonesia yang menganut sistem ekonomi terbuka dituntut untuk lebih siap agar dapat mengambil manfaat sebesarbesarnya dari keanggotaan Indonesia di WTO.

\section{Realisasi} Prinsip National Treatment dalam Penanaman Modal Asing di Indonesia sesungguhnya tidak menutup semua kemungkinan bagi Indonesia untuk memajukan Industri Nasional karena pada dasarnya GATT tidak melarang proteksi terhadap terhadap industri nasional selama proteksi yang diberikan hanya melalui tarif.

Peranan Negara dalam urusan-urusan ekonomi masih sangat penting mengingat masalah ekonomi dewasa ini bukan lagi merupakan urusan privatum atau keperdataan semata melainkan telah menjadi urusan publicum yang membenarkan Negara untuk ikut campur lewat hukum administrasi. ${ }^{6}$ Hal ini tidak hanya berlaku bagi egara-negara berkembang saja, konsep ini juga berlaku bagi Negara-negara maju yang menganut konsep welfare state.

\footnotetext{
${ }^{6}$ Soenaryati Hartono, Hukum Ekonomi Pembangunan, Bina Cipta, Bandung. 1988. Hlm.27
}

Penerapan Prinsip Non-Diskriminatif dan National Treatment dalam Kasus

\section{Pengadaan Mobil Nasional Indonesia}

Indonesia pernah ditarik masuk dalam penyelesaian sengketa GATT mengenai Program Mobil Nasional sebagaimana termuat dalam Keppres Nomor 42 Tahun 1996 dan peraturan pendukung lainnya. Indonesia diadukan oleh negara-negara industri seperti Jepang, Amerika Serikat dan Uni Eropa yang menganggap kebijakan tersebut melanggar Perjanjian TRIMs. Aduan tersebut berdasarkan pelanggaran yang dilakukan Indonesia mengenai larangan persyaratan local content requirement dengan argumen bahwa kebijakan tersebut memperkenankan kendaraan lengkap diproduksi di luar negeri kemudian diimpor ke dalam negeri dengan tarif mobil nasional. Keringanan pajak yang diterima mobil nasional dari Korea dianggap telah melanggar prinsip tersebut karena produk otomotif dari Negara lain seperti Jepang, Amerika Serikat dan Eropa dijual dengan harga lebih tinggi akibat pengenaan pajak yang jauh lebih tinggi.

Alasan tersebut membuat perusahaan atau produsen mobil asing yang berada di Indonesia melancarkan klaim bahwa Pemerintah Republik Indonesia telah melanggar Pasal I dan Pasal III GATT, Pasal 2 perjanjian TRIMs, Pasal 3, 6 dan 28 perjanjian SCM (Subsidi dan Imbalan Bea 
Masuk serta Pasal 3, 20 dan 65 Persetujuan TRIPs.

Putusan tersebut menyatakan bahwa persyaratan kandungan lokal (local content requirement) dalam program mobil nasional 1993 dan 1996 dan telah merugikan negaranegara Eropa karena bertentangan dengan Pasal 2 perjanjian TRIMs dan Article 27.4 Agreement on Subsidies and Contourveiling Measures sementara tuntutan lainnya tidak dikabulkan oleh Panel. Putusan ini mewajibkan Pemerintah Indonesia mencabut semua Keputusan Presiden beserta Peraturan lainnya yang terkait dengan persyaratan kandungan lokal.

Meskipun mendapat pembelaan dari India dan Korea, Pemerintah Indonesia tidak mengajukan banding atas putusan Panel tersebut. Yang patut dicatat adalah ketika kasus mobil nasional tersebut disidangkan Indonesia sedang mengalami krisis moneter dan sedang membutuhkan bantuan dana dari donor Internasional khususnya IMF. Indonesia dituntut untuk menyesuaikan peraturan penanaman modal agar tidak bertentangan dengan prinsip-prinsip WTO.

Hal ini menunjukkan bahwa dalam menerapkan suatu aturan yang sudah diratifikasi, Indonesia harus bertanggung jawab dan konsisten pula apabila terdapat kasus yang terindikasi melanggar prinsipprinsip yang terdapat di dalamnya. Prinsip Non-Diskrimatif dan National Treatment tetap harus ditegakkan tanpa terkecuali dalam menyama ratakan para penanam modal, baik asing maupun dalam negeri.

\section{Penutup}

Pemerintah Indonesia sudah menerapkan prinsip Non-Diskriminatif dan National Treatment atau perlakuan yang sama bagi penanam modal asing dengan menerapkan prinsip tersebut di dalam Undang-undang Nomor 25 Tahun 2007 tentang Penanaman Modal. Indonesia menerapkan Prinsip Non-Diskriminatif dan National Treatment dalam Kasus Pengadaan Mobil Nasional Indonesia dengan menjalani putusan yang mewajibkan Pemerintah Indonesia mencabut semua Keputusan Presiden beserta Peraturan lainnya yang terkait dengan persyaratan kandungan lokal.

\section{Daftar Pustaka}

An An Chandrawulan, (2011) Hukum Perusahaan Multinasional, Liberalisasi Hukum Perdagangan Internasional, dan Hukum Penanaman Modal, Alumni, Bandung.

Djuhaendah Hasan, S.H., (2007), 70 tahun prof. Dr. Djuhaendah Hasan, S.H. Universitas Padjadjaran.

Huala Adolf, (2004), Hukum Perdagangan Internasional, Raja Grafindo Persada, Jakarta. 2004.

Mahmul Siregar, (2005), Perdagangan Internasional dan Penanaman Modal", Universitas Sumatera Utara. Sekolah Pasca Sarjana.

Munir Fuady, (2005), Pengantar Hukum Bisnis:Menata Bisnis Modern di Era 
Global, Citra Aditya Bhakti, Bandung.

Muhammad Sood, (2012), Hukum Perdagangan Internasional, Jakarta: PT Raja. Grafindo Persada.

Soenaryati Hartono, (1988), Hukum Ekonomi Pembangunan, Bina Cipta, Bandung.

Peraturan Perundang-undangan:

Undang-undang Dasar Negara Republik Indonesia Tahun 1945

Undang-undang Nomor 1 Tahun 1967 tentang Penanaman Modal Asing

Undang-undang Nomor 25 Tahun 2007 tentang Penanaman Modal

\section{Internet:}

Jurnal: Dwi Martini, Judul: Prinsip National Treatment Dalam Penanaman Modal Asing Di Indonesia (Antara Liberalisasi Dan Perlindungan Kepentingan Nasional). Fakultas Hukum Universitas Mataram. 2012.

http://player.slideplayer.info/download/11/30 50821/o1fpRPM4wh1KVoIHrcmplw/ 1459864558/3050821.ppt. Diakses pada 4 Desember 2016, Pukul 20.25 WIB.

Martin Manurung. Diakses: http//www.indoprogress.com Diakses pada 4 Desember 2016, Pukul 21.00 WIB. 